\title{
Prevalence of dental caries among children aged 5-15 years from 9 countries in the Eastern Mediterranean Region: a meta-analysis
}

Sonal Kale ${ }^{1}$, Pradnya Kakodkar ${ }^{1}$, Sahana Shetiya ${ }^{1}$ and Rizwan Abdulkader ${ }^{2}$

${ }^{1}$ Dr DY Patil Vidyapeeth University, Maharashtra, India (Correspondence to: P. Kakokdar: pradnya.kakodkar@gmail.com). ${ }^{2}$ SBCM Joint Programme-Riyadh, Ministry of Health, Riyadh, Saudi Arabia.

\begin{abstract}
Background: Dental caries affects all age groups, although children are affected to a greater extent. Several studies have assessed the prevalence of dental caries in the World Health Organization (WHO) Eastern Mediterranean Region. However, prevalence data for dental caries have not been pooled for all countries in the Region.

Aims: To estimate by meta-analysis the pooled prevalence of dental caries among children aged 5-15 years in the Region.

Methods: The study protocol was registered in PROSPERO with registration number CRD42016037157. Twenty-one studies (37 estimates) were identified through systematic search for articles published between 1 January 2005 and 5 July 2018. The required data from each article were extracted into the datasheet. A random-effects meta-analysis was performed for the overall age group and for age 5, 12 and 15 years individually.

Results: Data were available for only 9 of the 21 countries in the Region. Heterogeneity between studies was high $\left(I^{2}>98 \%\right)$. There was considerable variation among the countries for the prevalence of dental caries at different ages. The pooled prevalence for deciduous dentition in children aged 5 years was $65 \%(45-85 \%) ; 61 \%(50-72 \%)$ for permanent dentition in children aged 12 years; $70 \%(64-75 \%)$ for children aged 15 years; and 66\% (59-73\%) for children aged $6-15$ years. The most common index used for oral examination to calculate caries experience was WHO Basic Oral Health Survey Criteria, 1997.
\end{abstract}

Conclusions: Dental caries continues to be an oral health concern among children in 9 countries in the Region.

Keywords: dental caries, prevalence, children, Eastern Mediterranean Region, meta-analysis

Citation: Kale S; Kakodkar P; Shetiya S; Abdulkader R. Prevalence of dental caries among children aged 5-15 years from 9 countries in the Eastern Mediterranean Region: a meta-analysis. East Mediterr Health J. 2020;26(6):726-735. https://doi.org/10.26719/emhj.20.050

Received: 10/09/18; accepted: 09/01/19

Copyright (c) World Health Organization (WHO) 2020. Open access. Some rights reserved. This work is available under the CC BY-NC-SA 3.0 IGO

license (https://creativecommons.org/licenses/by-nc-sa/3.o/igo).

\section{Introduction}

Dental caries has long been a global oral health burden (1). It not only affects oral health but also has a deleterious effect on overall health and quality of life (2), especially in underprivileged countries (3). The World Health Organization (WHO) reports that $60-90 \%$ of children are affected by dental caries (4). Dental caries affects all age groups, although children are affected to a greater extent than adults. Part of the solution to overcome this problem is to estimate the current burden accurately and plan for a comprehensive dental programme. The WHO Country Area Profile Program database maintains data on caries prevalence data. However, there are a few limitations : data are not available for all age groups and all the WHO countries; and if data are available, they are not updated on a regular basis. In the WHO Eastern Mediterranean Region, data are available but they are not updated on a regular basis (5). In 2018, Al Ayyan et al. conducted a meta-analysis of the Gulf countries in the Region, and found that prevalence of caries in deciduous teeth was $80.9 \%(6)$.

To obtain a complete picture of the dental caries situation among children in all the countries in the Region, a meta-analysis has been planned, which will provide evidence-based information, based upon which, appropriate health care policies can be developed. Along with prevalence, it is also essential to evaluate the various indices used in the published literature for assessing caries, as different indices give varying results within the same populations (7). For example, the International Caries Detection and Assessment System (ICDAS) considers even white spots as caries, while the traditional Decayed Missing and Filled (DMF) index ignores noncavitated enamel lesions, leading to underestimation of caries (8).

The aim of this review was to assess prevalence of caries among children aged 5-15 years by conducting a meta-analysis, and to identify the most common indices used for estimating caries prevalence in the Region.

\section{Methods}

This study was part of a bigger review that was conducted to estimate prevalence of caries across all WHO regions. The review protocol is registered in PROSPERO (registration number CRD42016037157). Here, we discuss only the meta-analysis pertaining to the Eastern Mediterranean Region.

\section{Literature search}

A literature search was conducted in PubMed and Google Scholar for the relevant articles using a preset search strategy. The keywords used were "Dental caries AND 
Prevalence AND Children AND (name of country)". Only articles published between 1 January 2005 and 5 July 2018 were considered. The search was carried out independently by 1 author (SK) and was verified by 2 others (PK and SHS). The inclusion criteria were: studies that were community based, cross-sectional, English language, and conducted among children aged 5-15 years. Only those studies providing data about children native to the countries of the Region were retrieved. Exclusion criteria were: studies that were conducted with a secondary objective to identify prevalence; studies on caries association and correlation with risk factors; studies on immigrants and special groups; studies including one gender only; and short communications and letters to the editor.

\section{Data extraction}

Study characteristics such as authors' names, year of publication, age/age group included, sample size, index used, prevalence of dental caries, type of dentition and risk factors for dental caries are summarized in Appendix $1(9-29)$. The caries prevalence of permanent dentition (D) for the age group 6-15 years and caries prevalence of deciduous dentition(d)for the age group 5-15 years were calculated separately. The caries prevalence represented the D component and d component of the Decayed, Missing and Filled Teeth (DMFT) and dmft indices (DMFT is for permanent teeth and dmft for deciduous teeth). The $D$ and $d$ component of DMFS (Decayed, Missing and Filled Surface )and dmfs (deciduous teeth) were not considered.
Caries prevalence data were extracted for individual ages. If individual age prevalence was not mentioned, the combined prevalence of age groups (e.g., 6-15 and 8-10 years) was considered. If prevalence was not mentioned but data about the $\mathrm{D}$ and $\mathrm{d}$ components, along with the total sample size, were available, the prevalence rate was calculated.

\section{Quality Assessment}

The quality assessment of the included studies was performed based on the criteria reported by Kale et al. (30).

\section{Statistical analysis}

A random-effects meta-analysis was performed to estimate the pooled prevalence and $95 \%$ confidence intervals (CIs) and were depicted by means of forest plots. Heterogeneity was quantified using I2 statistics. Separate meta-analyses were performed for ages 5,12 and 15 years and overall for 6-15 years. All analyses were performed using STATA version 12.

\section{Results}

A total of 259 articles from PubMed and 12 from Google Scholar were retrieved initially (Figure 1). After reviewing the titles of the articles, 133 were excluded, as they did not fit the selection criteria. After reading through the abstracts of the remaining articles, 17 more were excluded. An in-depth reading of the remaining articles led to the exclusion of 7 more, for reasons such as not mentioning the prevalence, inclusion of children aged $>15$ years, and

Figure 1 PRISMA flow chart showing the article selection process

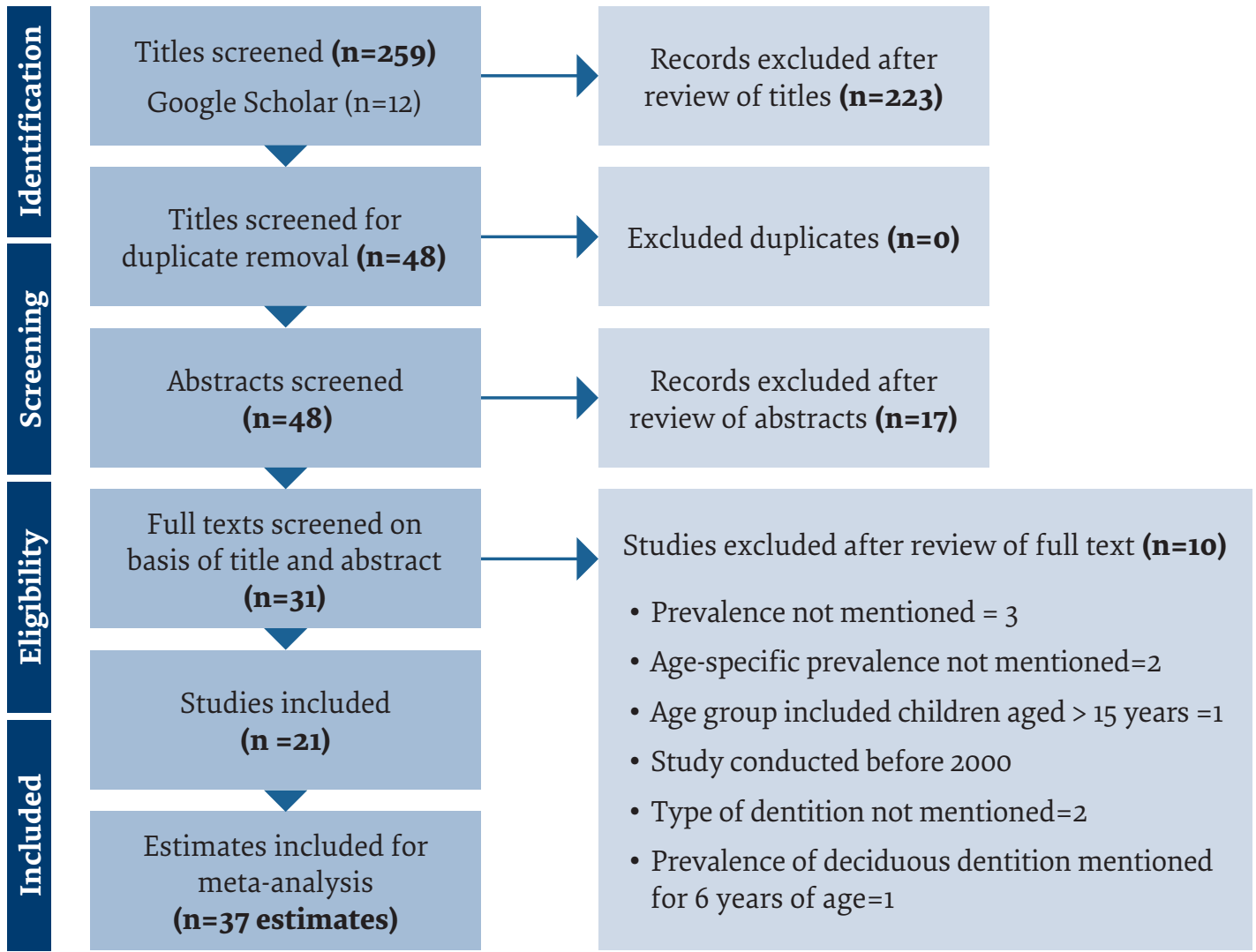


providing prevalence of deciduous and permanent dentition together. Ultimately, 21 articles with 37 estimates were considered for meta-analysis. Relevant literature was only found for 9 of the 21 countries currently in the Eastern Mediterranean Region [Islamic Republic of Iran, Iraq, Yemen, Jordan, Libya, United Arab Emirates (UAE), Bahrain, Lebanon and Egypt). For children aged 5 years there were 4 estimates; for children aged 12 years there were 11 estimates; for children aged 15 years there were 7 estimates; and for children aged 6-15 years there were 33 estimates available. Only 2 studies that were reported by Ahmadzadeh et al. (15) and Hamza (17) were found to have moderate quality as per quality assessment criteria (30). All other studies were of high quality and none was of low quality.

The heterogeneity between the studies was high ( $I^{2}$ $>98 \%$ ) and therefore an aggregate data random-effect model was adopted for the meta-analysis. The pooled prevalence for deciduous dentition for children aged 5 years was 65\% (95\% CI: 45-85\%) (Figure 2); 61\% (95\% CI: $50-72 \%)$ for permanent dentition in children aged 12 years (Figure 3); 70\% (95\% CI: 64-75\%) for children aged 15 years (Figure 4); and 66\% (95\% CI: 59-73\%) for children aged 6-15 years (Figure 5). Based on the data extracted from each included study, the index information was obtained (Appendix 1). The number of times the index was used was totalled to meet the second objective. The most common index used for evaluating dental caries experience was the WHO Basic Oral Health Criteria, 1997 (used in 13 studies), followed by the DMFT index, 1937 (3 studies), WHO Basic Oral Health Criteria, 1987 (3 studies) and WHO Basic Oral Health Criteria, 2013 (2 studies).

\section{Discussion}

Several studies have been conducted in the Eastern Mediterranean Region to assess the prevalence of dental caries. However, there has been no effort to pool the prevalence data for all the countries in the Region. Hence, this meta-analysis was conducted to obtain prevalence data for dental caries in children aged 5-15 years in the Region, and to establish the most frequently used index for assessing caries in these studies. The pooled prevalence obtained for children aged 5 years was $65 \%$. This is lower than the prevalence of $80.95 \%$ in Gulf countries reported by Al Ayyan et al. (6). Despite the fact that it is lower than the previously reported prevalence, it still does not meet the target set of $50 \%$ caries free by WHO in 2000 (31). Our review had data from only 4 studies of deciduous teeth, while the review by Al Ayyan et al. (6) included 34 studies from 1992-2016. This might explain the variation in prevalence. Three of the 4 estimates in the present study were from the UAE and the other was from Yemen. The reason reported for dental caries in these studies was the negative attitude of parents towards their children's dental health.

For the children aged 12 years, the pooled prevalence was $61 \%$. This result was obtained by pooling the prevalence from the Islamic Republic of Iran, Jordan, Yemen, Libya, United Arab Emirates, Iraq, Bahrain and Lebanon. Dental caries in this age group was attributed to low socioeconomic status, low parental education, consumption of refined food and poor access to dental services. Two studies $(13,19)$ reported low socioeconomic status to be the reason for high prevalence of caries, whereas another (28) reported it as a reason for low prevalence of caries.

Among children aged 15 years, the prevalence of dental caries was $70 \%$. This was contributed by studies from the Islamic Republic of Iran, UAE, Bahrain and Lebanon. Poor oral hygiene practices among children, consumption of cariogenic diet and low socioeconomic status were the reported factors for the presence of dental caries.

The most common dental caries indices used were WHO criteria 1987, 1997 and 2013 and the DMFT index proposed by Klein, Palmer and Knutson (1937). Castro et al. (8) conducted an interview to investigate the populationbased caries detection methods and reported that DMFT index was the most known and used index. However, 95.7\% were dissatisfied with the index yet continued to use it. It is recommended that researchers use the WHO Basic Oral Health Survey criteria for assessing caries, which will provide global uniformity and aid effective comparison.

Overall, the pooled prevalence of permanent dentition in children aged 6-15 years was $66 \%$. There was huge








$(A-C)$ as in footnote to Table 1. $C I=$ confidence interval; $E S=$ estimate; $I^{2}=$ heterogeneity.

variation among the prevalence rates, with the lowest of $22 \%$ reported by Said-Moallemi et al. (11) and the highest of $94 \%$ reported by Doumit and Doughan (21). The reasons for high prevalence of caries were low socioeconomic status, cariogenic diet, low parental education, less accessibility to dental care services, and dental health negligence. The reasons for low prevalence of caries were widespread use of fluoridated toothpaste (18) and implementation of a national oral health programme (11). This variation can be attributed to different geographic locations, differences in the individuals included in the study, variation in sample size, and the use of different indices for assessing caries. Oral health policies, community water fluoridation and oral hygiene products also play a role in the variation among countries. Low levels of water fluoridation are found in most provinces in the Islamic Republic of Iran and only $22 \%$ of the Libyan population receive fluoridated water (32). Until 2003, the United Nations had imposed sanctions on the amount of food provided to Iraq, which included freely available

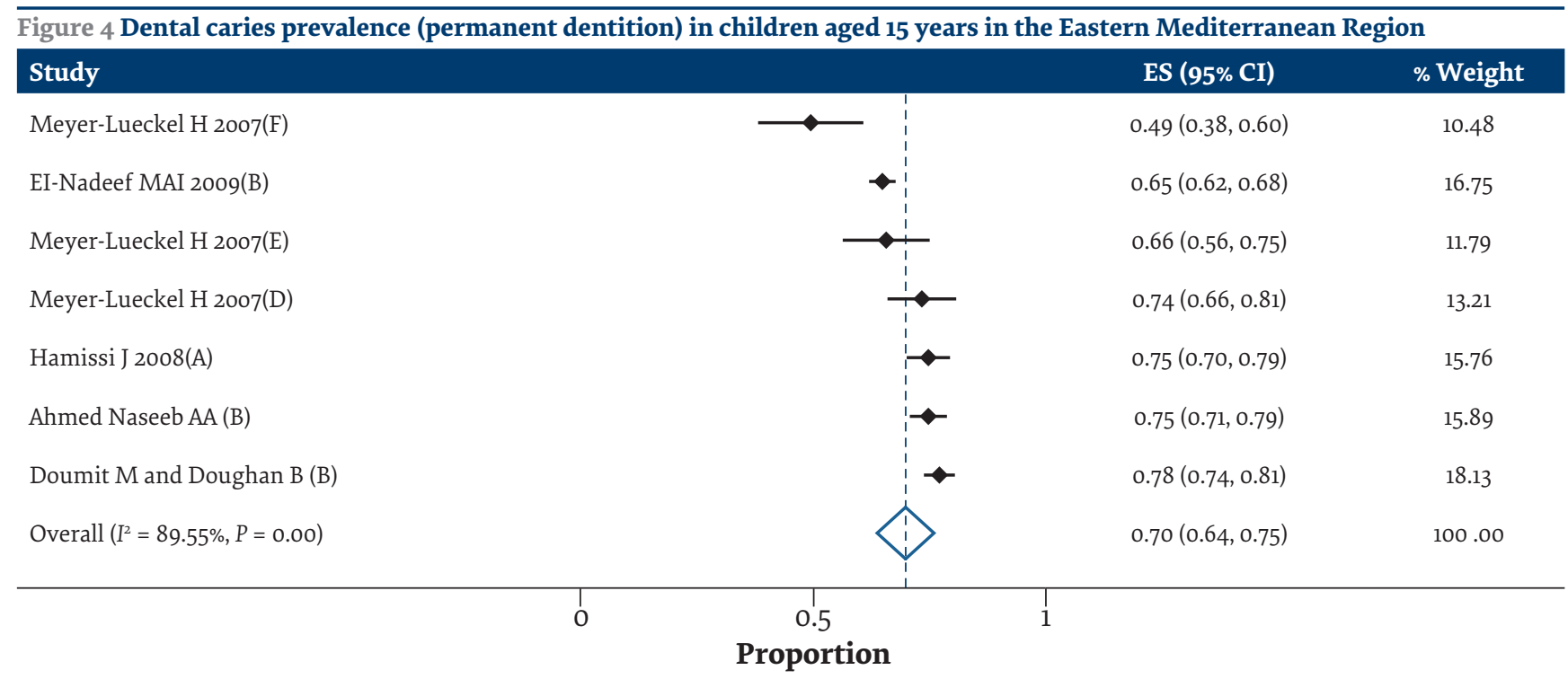


Figure 5 Dental caries prevalence (permanent dentition) in children aged 6-15 years in the Eastern Mediterranean Region Study ES $(95 \% \mathrm{CI})$ $\%$ Weight

Saied-Moallemi Z

Ahmadzadah J (A)

Al Mashhadani SS (B)

Meyer-Lueckel H (i) (C)

Meyer-Lueckel H (i) (A)

Rajab LD (B)

Meyer-Lueckel H (i)(F)

EI-Nadeef MAI (i)(A)

Meyer-Lueckel H (i)(B)

Hamza HA

Huew R

Ahmed NAM

Hewida M. EJ Shazly and Hala M. Gabr

EI-Nadeef MAI (i)(B)

Meyer-Lueckel H (i)(E)

Meyer-Lueckel H (ii)(E)

Ahmed Naseeb AA (B)

Ahmadzadeh J (B)

Mayer-Lueckel H (ii)(F)

Meyer-Lueckel H (i)(D)

Ahmed Naseeb AA (C)

Hamissi J

EL-Qaderi SS and Taani DQ

Meyer-Lueckel H (ii)(D)

Doumit M and Doughan B (C)

Smadi L

Mayer-Lueckel H (ii)(A)

Mayer-Lueckel H (ii)(B)

Ahmadzadeh J (C)

Doumit and Doughan B (B)

Meyer-Lueckel H (ii)(C)

Al-Otaibi MF

Doumit M and Doughan B (A)

Overall $\left(I^{2}=99.06 \%, P=0.00\right)$
$0.22(0.18,0.26)$

3.09

$0.26(0.21,0.32)$

3.05

$0.42(0.40,0.44)$

3.11

$0.45(0.35,0.56)$

2.88

$0.45(0.36,0.54)$

2.95

$0.46(0.44,0.47)$

3.11

$0.49(0.38,0.60)$

2.87

$0.54(0.51,0.57)$

3.10

$0.55(0.45,0.65)$

2.90

$0.55(0.50,0.60)$

3.07

$0.58(0.54,0.61)$

3.09

$0.62(0.57,0.67)$

3.07

$0.63(0.60,0.65)$

3.10

$0.65(0.62,0.68)$

3.10

$0.66(0.58,0.75)$

2.94

$0.70(0.60,0.78)$

2.93

$0.70(0.67,0.73)$

3.10

$0.71(0.62,0.79)$

2.96

$0.73(0.62,0.81)$

2.92

$0.74(0.65,0.80)$

3.00

$0.75(0.71,0.79)$

3.08

$0.75(0.71,0.79)$

3.08

$0.76(0.74,0.78)$

3.11

$0.77(0.69,0.84)$

2.98

$0.78(0.74,0.81)$

3.09

$0.79(0.76,0.81)$

3.11

2.98

3.00

2.98

3.10

2.95

3.10

3.11

100.00

\section{Proportion}




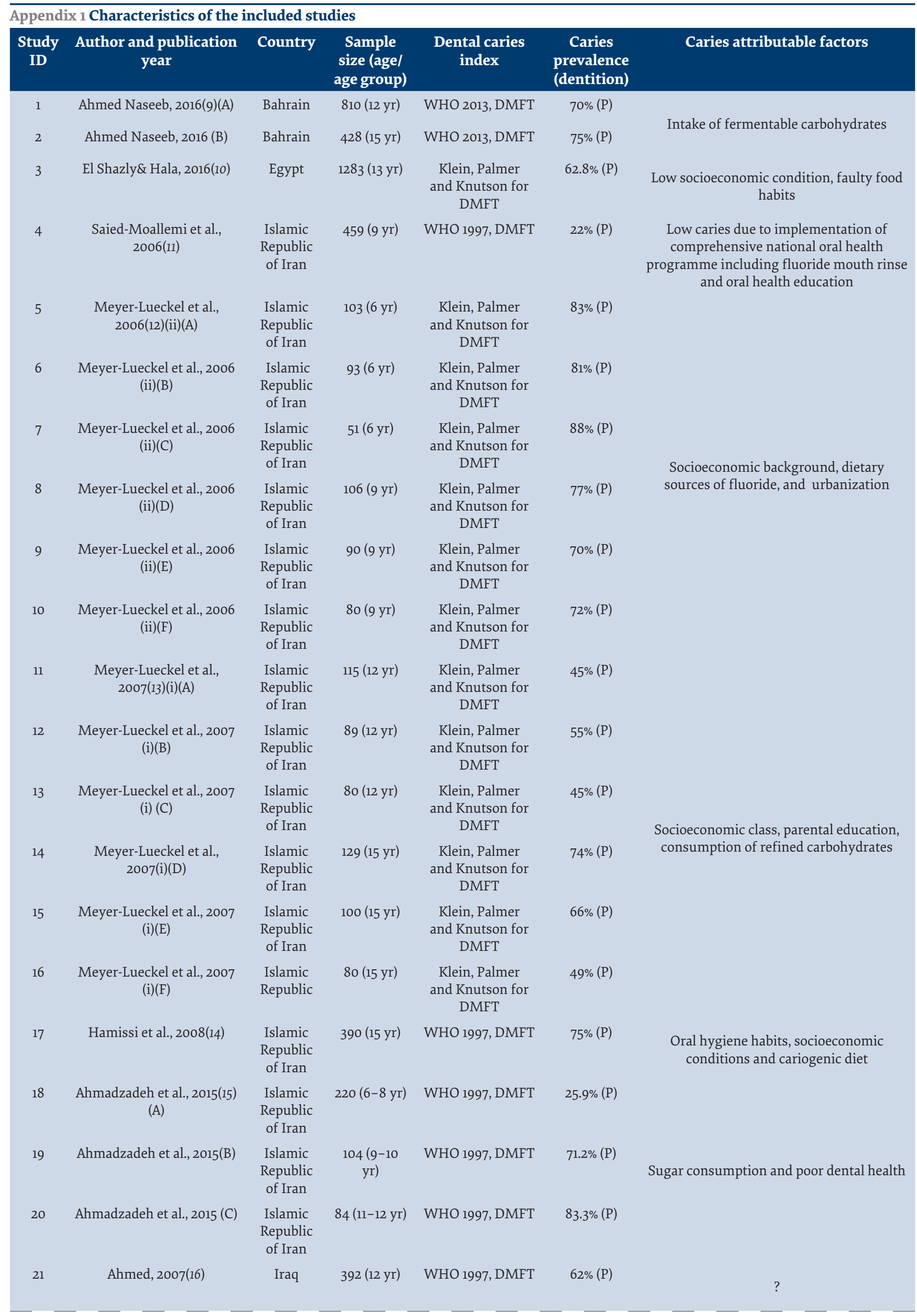




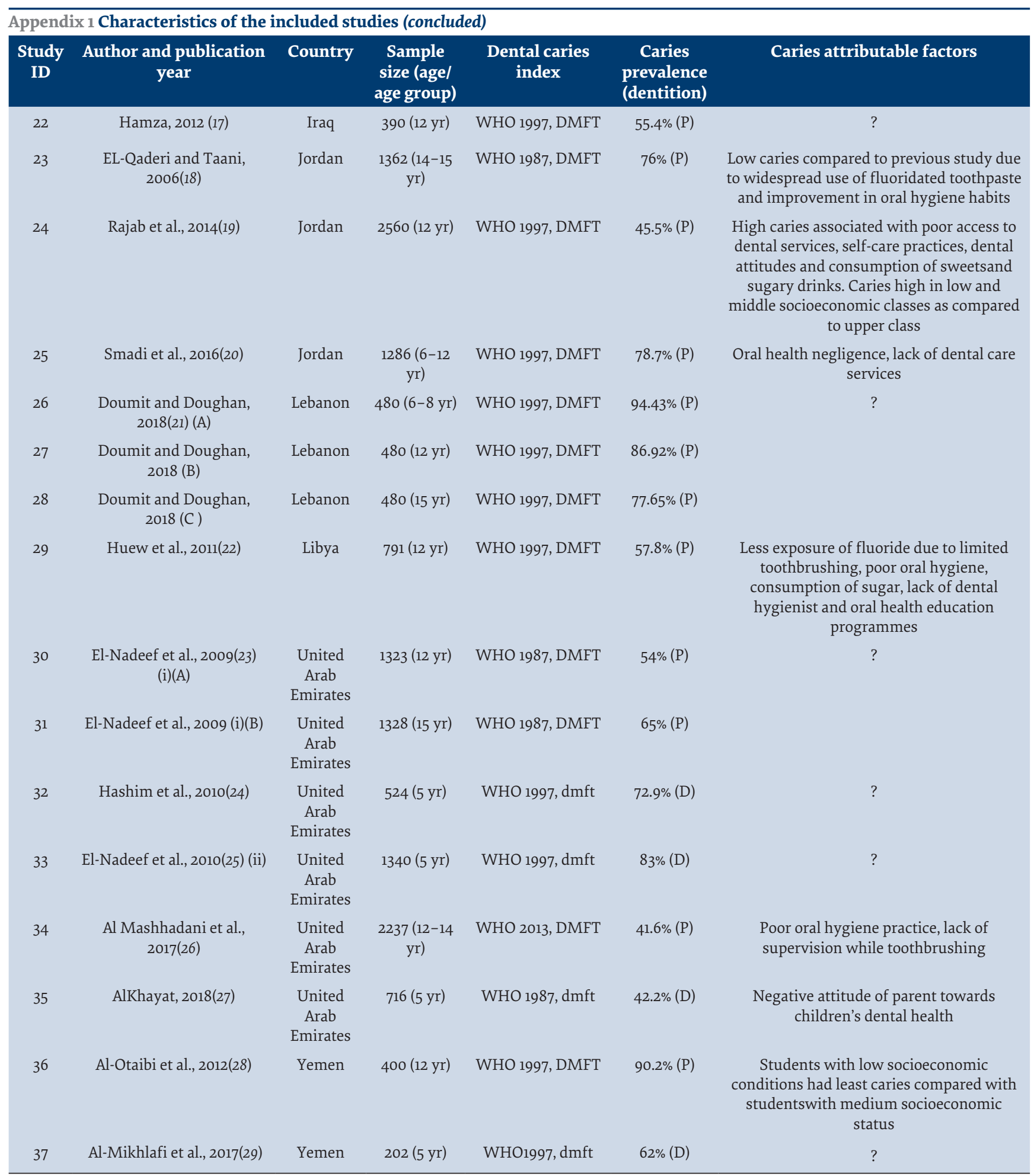

$\mathrm{D}=$ deciduous dentition prevalence, $\mathrm{P}=$ permanent dentition prevalence, $?=$ factors not mentioned. $(\mathrm{A}-\mathrm{F})$ are same studies representing different age/age group data. (i, ii) represent two different studies reported by the same author in the same year.

sugar (33), but after 2003 the amount of sugar increased and thus consumption of sugar also increased, which is one of the key causative factors of caries. No literature was found with respect to the oral health policies of the countries included in this analysis.

There were some limitations to our meta-analysis. First, only 2 databases were searched. Second, only English-language articles were selected. In cases where a combined prevalence (deciduous + permanent) was mentioned, such studies were excluded. Caries prevalence should be reported separately for deciduous and permanent dentition, which aids effective metaanalysis. The meta-analysis was intended to cover the Eastern Mediterranean Region; however, data were only available from 9 countries (Islamic Republic of Iran, Iraq, Yemen, Jordan, Libya, UAE, Bahrain, Lebanon and Egypt). No information was available for countries 
like Djibouti and Oman. However, for other countries in the Region, some oral health information was available but these articles were not selected as they did meet the inclusion criteria.

\section{Conclusion}

Within the limitations of this meta-analysis, it can be concluded that dental caries in children is still a major problem in the 9 countries studied in the Region. More studies reporting dental caries from all the countries in the Region are required to obtain an accurate picture of dental caries prevalence among children in the Region.

Funding: None.

Competing interests: None declared.

\section{Prévalence des caries dentaires chez les enfants âgés de 5 à 15 ans originaires de neuf pays de la Région de la Méditerranée orientale : méta-analyse}

\section{Résumé}

Contexte : Les caries dentaires concernent tous les groupes d'âge, bien que les enfants soient plus largement touchés. Plusieurs études ont évalué la prévalence des caries dentaires dans la Région de l'Organisation mondiale de la Santé (OMS) pour la Méditerranée orientale. Cependant, les données sur la prévalence des caries dentaires n'ont pas été mises en commun pour l'ensemble des pays de la Région.

Objectifs : La présente étude avait pour objectif d'estimer par méta-analyse la prévalence globale des caries dentaires chez les enfants âgés de 5 à 15 ans dans la Région.

Méthodes : Le protocole d'étude a été enregistré dans PROSPERO sous le numéro CRD42016037157. Vingt-et-une études (37 estimations) ont été identifiées au moyen d'une recherche systématique des articles publiés entre le $1^{\text {er }}$ janvier 2005 et le 5 juillet 2018. Les données requises pour chaque article ont été extraites puis reportées dans la fiche technique. Une méta-analyse à effets aléatoires a été réalisée pour l'ensemble de la classe d'âge et individuellement pour les groupes des 5,12 et 15 ans.

Résultats : Les données étaient disponibles pour seulement neuf des 21 pays que compte la Région. L'hétérogénéité entre les études était élevée ( $\left.\mathrm{I}^{2}>98 \%\right)$. On a observé des variations considérables entre les pays en ce qui concerne la prévalence des caries dentaires à différents âges. La prévalence globale pour les dents de lait chez les enfants âgés de 5 ans était de $65 \%(45-85 \%)$; de $61 \%(50-72 \%)$ pour les dents définitives chez les enfants âgés de 12 ans ; de 70 \% (64-75\%) chez les jeunes âgés de 15 ans et de $66 \%$ (59-73\%) chez les enfants dont l'âge est compris entre 6 et 15 ans. L'indice le plus couramment utilisé pour l'examen bucco-dentaire destiné à évaluer les lésions carieuses était celui des Enquêtes sur la santé bucco-dentaire de l'OMS, méthodes fondamentales.

Conclusions : Les caries dentaires demeurent un problème de santé bucco-dentaire chez les enfants dans neuf pays de la Région.

$$
\text { شعرل المتنشار تسوس الأسنان في صفوف الأطفال الذين تتراوح أعلارهم بين } 5 \text { سنوات و } 15 \text { سنة في } 9 \text { بُلدان في إقليم }
$$

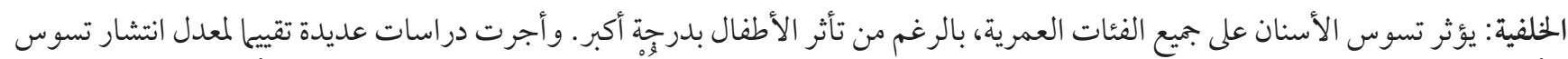

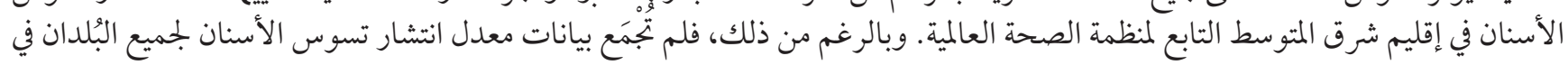

الأهداف: هدفت هذه الدراسة إلى تقييم معدل انتشار تسوس الأسنان وفق البيانات المجموعة عن طريق التحليل التلوي في صفوف الأطفال الذين تتراوح أعحارهم بين 5 سنو ات و و 15 سنة في الإقليم.

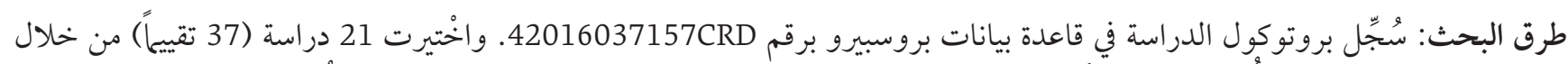

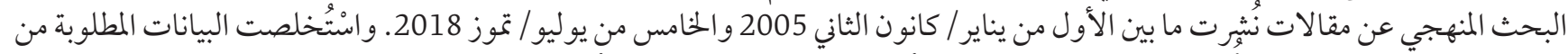





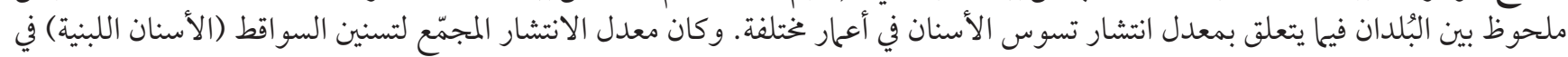

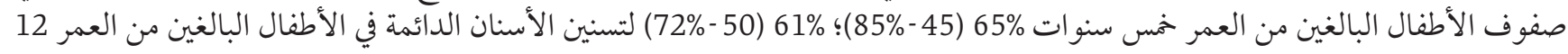




$$
\begin{aligned}
& \text { عاماً 70\% (64 - 75\%) للأطفال البالغين من العمر } 15 \text { عاماً؛؛ 66\% (59 - 73\%) للأطفال الذين تتراوح أعمارهم بين } 6 \text { سنو الات و } 15 \text { سنة سنة. و وكان المؤشر }
\end{aligned}
$$

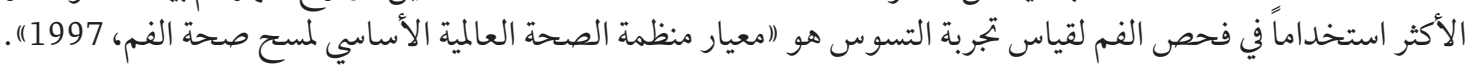

$$
\begin{aligned}
& \text { الاستتاجات: يظل تسوس الأسنان ظاهرة تبعث على القلق في صفوف الأطفال في } 9 \text { بُّلدان في الإقليم. }
\end{aligned}
$$

\section{References}

1. Petersen PE. Continuous improvement of oral health in the 21st century - the approach of the WHO Global Oral Health Programme. Geneva: World Health Organization; 2003 (https://www.who.int/oral_health/media/en/orh_reporto3_en.pdf, accessed 20 December 2019).

2. Al Agili DE. A systematic review of population-based dental caries studies among children in Saudi Arabia. Saudi Dental J. 2013 Jan; 25(1): 3-11. http://dx.doi.org/10.1016/j.sdentj.2012.10.002 PMID:23960549

3. Sharma A, Bansal P, Grover A, Sharma S, Sharma A. Oral health status and treatment needs among primary school going children in Nagrota Bagwan block of Kangra, Himachal Pradesh. J Indian Soc Periodontol. 2014 Nov-Dec;18(6):762-6. http://dx.doi. org/10.4103/0972-124X.147421 PMID:25624634

4. Fact sheets: oral health [website]. Geneva: World Health Organization (https://www.who.int/news-room/fact-sheets/detail/oralhealth, accessed 20 December 2018).

5. Oral health country/area profile project [website]. Malmo University (https://www.mah.se/CAPP/Country-Oral-Health-Profiles/ EMRO, accessed 20 December 2019).

6. Al Ayyan W, Al Halabi M, Hussein I, Khamis AH, Kowash M. A systematic review and meta-analysis of primary teeth caries studies in Gulf Cooperation Council States. Saudi Dent J. 2018 Jul;30(3):175-82. http://dx.doi.org/10.1016/j.sdentj.2018.05.002 PMID:29942100

7. Joseph C, Velley AM, Pierre A, Bourgeois D, Muller-Bolla M. Dental health of 6-year-old children in Alpes Maritimes, France. Eur Arch Paediatr Dent. 2011 Oct;12(5):256-63. PMID:21993066

8. Castro ALS, Vianna MIP, Mendes CMC. The knowledge and use of population-based methods for caries detection.BMC Oral Health. 2018 Aug 29:18(1):153. http://dx.doi.org/10.1186/s12903-018-0612-5 PMID:30157818

9. Ahmed Naseeb AA. National oral health survey of oral health status of Bahraini school children aged 6,12 \& 15 year olds. Dental News. 19 July 2016 (http://dentalnews-articles.blogspot.com/2016/07/national-oral-health-survey-of-oral.html, accessed 20 December 2019).

10. El Shazly HM, Hala MG. Prevalence and risk factors of dental caries among preparatory school children, Menoufia Governorate, Egypt. Asian J Med Health. 2016;1(6):1-11. https://doi.org/10.9734/AJMAH/2016/30174

11. Saied-Moallemi Z, Virtanen JI, Tehranchi A, Murtomaa H. Disparities in oral health of children in Tehran, Iran. Eur Arch Paediatr Dent. 2006 Dec;7(4):262-4. http://dx.doi.org/10.1007/bfo3262563 PMID:17164073

12. Meyer-Lueckel H, Paris S, Shirkhani B, Hopfenmuller W, Kielbassa AM. Caries and fluorosis in 6- and 9-year-old children residing in three communities in Iran. Community Dent Oral Epidemiol. 2006 Feb;34(1):63-70. http://dx.doi.org/10.1111/j.160o0528.2006.00258.x PMID:16423033

13. Meyer-Lueckel H, Bitter K, Shirkhani B, Hopfenmuller W, Kielbassa AM. Prevalence of caries and fluorosis in adolescents in Iran. Quintessence Int. 2007 Jun;38(6):459-65. PMID:17625628

14. Hamissi J, Ramezani GH, Ghodousi A. Prevalence of dental caries among high school attendees in Qazvin, Iran. J Indian Soc Pedod Prev Dent. 2008;26(Suppl 2):S53-5. PMID:19075448

15. Ahmadzadeh J, Rezaeian S, Esmahili-Sani A, Lava B, Mobaraki K, Amini S and Amini S. Oral health status and behaviors of children aged 6-12 years old: a cross-sectional study. Ann Public Health Res. 2015;2:1017.

16. Ahmed NA, Astrøm AN, Skaug N, Petersen PE. Dental caries prevalence and risk factors among 12-year old schoolchildren from Baghdad, Iraq: a post-war survey. Int Dent J. 2007 Feb;57(1):36-44. http://dx.doi.org/10.1111/j.1875-595x.2007.tboo116.x PMID:17378348

17. Hamza HA. Oral health status and treatment needs among twelve year old school children in Babylon Governorate - IRAQ. J Babylon Univ Pure Appl Sci. 2012;20(3). https://www.iasj.net/iasj?func=fulltext\&aId=77862

18. El-Qaderi SS, Quteish Ta'ani D. Dental plaque, caries prevalence and gingival conditions of 14-15-year-old schoolchildren in Jerash District, Jordan. Int J Dent Hyg. 2006 Aug;4(3):150-3. http://dx.doi.org/10.1111/j.1601-5037.2006.00184.x PMID:16958744

19. Rajab LD, Petersen PE, Baqain Z, Bakaeen G. Oral health status among 6- and 12-year-old Jordanian schoolchildren. Oral Health Prev Dent. 2014;12(2):99-107. http://dx.doi.org/10.3290/j.ohpd.a31220 PMID:24624383

20. Smadi L, Azab R, Khlaifat F, Rodan R, Abdalmohdi A, Rudina M, et al. Prevalence and severity of dental caries in school students aged 6-12 years in Mafraq governorate: Northeast of Jordan. J Oral Health Oral Epidemiol. 2017 Winter;6(1):40-7.

21. Doumit M, Doughan B. Dental caries and fluorosis among children in Lebanon. Indian J Dent Res. 2018 May-Jun;29(3):317-22. http://dx.doi.org/10.4103/ijdr.IJDR_475_17 PMID:29900915

22. Huew R, Waterhouse PJ, Moynihan PJ, Maguire A. Prevalence and severity of dental caries in Libyan schoolchildren. Int Dent J. 
2011 Aug;61(4):217-23. http://dx.doi.org/10.1111/j.1875-595X.2011.00060.x PMID:21851354

23. El-Nadeef MAI, Hussani EA, Hassab H, Arab IA. National survey of the oral health of 12- and 15-year-old schoolchildren in the United Arab Emirates. East Mediterr Health J. 2009 Jul-Aug;15(4):993-1004. PMID:20187552

24. Hashim R, Williams SM, Thomson WM, Awad MA. Caries prevalence and intra-oral pattern among young children in Ajman. Community Dent Health. 2010 Jun;27(2):109-13. PMID:20648888

25. El-Nadeef MA, Hassab H, Al-Hosani E. National survey of the oral health of 5-year-old children in the United Arab Emirates. East Mediterr Health J. 2010 Jan;16(1):51-5. PMID:20214158

26. Al Mashhadani. SS, Khoory TA, Fargali K, Mathew R, Al Qasem N. National Survey of the Oral Health Status of School Children in Dubai, UAE. EC Dent Sci .2017;8.2: 48-58. https://www.ecronicon.com/ecde/pdf/ECDE-08-00258.pdf

27. AlKhayat M. Caries survey in 3-5 year old children in Dubai Schools. Inter Ped Dent Open Acc J. 2018 Jan;1(1):1-7. http://dx.doi. org/10.32474/IPDOAJ.2018.01.000101

28. Al-Otaibi MF, Al-Mamari F, Baskaradoss JK. Oral health status of 12-year-old school children in Yemen. A cross- sectional survey. Eur J Paediatr Dent. 2012 Dec;13(4):324-8. PMID:23270293

29. Al-MikhlafiAM, Al-Labani MA, Al-Haddad KA, Al-Serouri AA, Al-Ghazali N. The Prevalence of dental caries in kindergartens' and its associated factors among children in Sana'a City. EC Dental Science. 2017;7.5:206-11. https://www.ecronicon.com/ecde/pdf/ ECDE-07-0000243.pdf

30. Kale SS, Kakodkar P, Shetiya SH, Rizwan SA. Dental caries prevalence among 5- to 15-year-old children from SEAR countries of WHO: A systematic review and meta-analysis. Indian J Dent Res. 2019;30(6):937-947. doi:10.4103/ijdr.IJDR_654_17

31. Aggeryd T. Goals for oral health in the year 2000: cooperation between WHO, FDI and the national dental associations. Int Dent J. 1983 Mar;33(1):55-9. PMID:6574111

32. Cochrane N, Poureslami H. Necessity of water fluoridation in Iran: A review on water fluoridation and prevention of dental caries. J Oral Epidemiol. 2014 Winter \& Spring;3(1):1-7. http://johoe.kmu.ac.ir/article_84790_4fbb66fa43f99523e7ff5be1469fd97a.pdf

33. Joury E, Al-Kaabi R, Tappuni AR. Constructing public health policies in post crisis countries: lessons to learn from the associations between free-sugars consumption and diabetes, obesity and dental caries before, during and after sanctions in Iraq. J Public Health. 2016;24:563-9. https://link.springer.com/article/10.1007/s10389-016-0745-4 